\title{
Races of Puccinia graminis in the United States During 1995
}

D. V. McVey, Research Plant Pathologist, and D. L. Long, Plant Pathologist, Cereal Rust Laboratory, Agricultural Research Service, USDA, University of Minnesota, St. Paul 55108, and J. J. Roberts, Research Plant Pathologist, Cereal Rust Research, Agricultural Research Service, USDA, Georgia Agricultural Experiment Station, Experiment 30212

\begin{abstract}
McVey, D. V., Long, D. L., and Roberts, J. J. 1997. Races of Puccinia graminis in the United States during 1995. Plant Dis. 81:306-310.

Wheat stem rust overwintered in southern Louisiana, southern Texas, southwestern Georgia, northeastern Arkansas, and southwestern South Carolina in the winter of 1994-95. Wheat stem rust caused negligible yield losses in wheat in the United States. Races Pgt-TPMK and QCCJ made up 39 and $31 \%$ of all isolates, respectively. Race TPMK comprised $67 \%$ of isolates from farm fields. Race Pgt-QCCJ was most common from barley, making up 93\% from 47 collections. Six collections from Hordeum jubatum yielded six isolates each of races QCCJ and QFCS, and one isolate of race TPMK. No virulence was found to wheat lines with genes $\operatorname{Sr} 6$, $9 \mathrm{~b}, 13,22,24,25,26,27,29,30,31,32,33,37, \mathrm{Gt}$, or $\mathrm{Wdl}-1$. Oat stem rust overwintered in plots at Beeville and Temple, Texas, in a field near San Antonio, and in southern Louisiana. Yield losses due to oat stem rust in 1995 were negligible. Race NA-27, virulent to $P g-1,-2,-3$, -4 , and -8 , was again the predominant race in the United States, comprising $82 \%$ of the 225 isolates from 80 collections. NA-5 and NA-16 were the two other races identified from the United States, comprising 11 and $19 \%$ of the isolates. Only race NA-29 was found in four collections from Mexico.
\end{abstract}

Puccinia graminis Pers.:Pers. is a major pathogen of many small grains worldwide. Epidemics in the United States have been rare since the virtual elimination of susceptible Berberis vulgaris L. from the cereal-producing areas of the northern Great Plains (5). The use of resistant wheat cultivars (Triticum aestivum L.) also contributed to control of stem rust. No major losses from stem rust have occurred in the United States in spring wheat since the mid-1950s or in winter wheat since the mid-1960s (4; D. L. Long, unpublished). However, $P$. graminis f. sp. tritici Eriks. \& E. Henn. race Pgt-QCCJ $(11,12)$ continues to threaten the barley crop in Minnesota, Manitoba, and the Red River Valley of North Dakota. There have been no major losses to oat stem rust since 1975 (4; D. L.

Corresponding author: D. V. McVey, USDA, Agricultural Research Service, Cereal Rust Laboratory, University of Minnesota, St. Paul 55108;

E-mail: donm@puccini.crl.umn.edu.

Paper No. 22-620, Scientific Journal Series, Minnesota Agricultural Experiment Station.

Accepted for publication 17 December 1997.

Publication no. D-1997-0128-04S

This article is in the public domain and not copyrightable. It may be freely reprinted with customary crediting of the source. The American Phytopathological Society, 1997.
Long, unpublished). The majority of the oat cultivars (Avena sativa L.) grown are susceptible to race NA-27, the most common race of $P$. graminis $\mathrm{f}$. $\mathrm{sp}$. avenae Eriks. \& E. Henn. (1). The lack of oat stem rust epidemics could be due to small numbers of overwintering uredinia or to late onset of disease $(9,12)$, small area of oats grown, or unfavorable environmental conditions for development of regional epi- demics. The trend in recent years is for a single race to make up most of the pathogen population (8).

This research is part of the continuing effort to monitor changes in race combinations present in P. graminis in an effort to maintain rust-resistant cultivars in North America.

\section{MATERIALS AND METHODS}

Surveys were made over a 22,000-km route covering the Great Plains, Ohio River Valley, and Gulf Coast of the United States. The surveys followed a preselected route through areas where small grain cereals are important and rust has historically been a problem. In 1995, field surveys of small grain cereals were made in the following areas: southern and central Georgia (late March through May); eastern and southern Texas (early April); northern Texas and south central Oklahoma (late April); southeastern Gulf Coast (midApril to early May); southeastern states (early May); Oklahoma and Kansas (midMay); the Ohio River Valley (early June); northwestern Kansas and Nebraska, western Iowa and South Dakota, and southern Minnesota (mid-June); and northern Plains states (early July and again in late July).

Table 1. A key for defining the Pgt-code races of Puccinia graminis f. sp. tritici

\begin{tabular}{|c|c|c|c|c|c|}
\hline \multirow[b]{5}{*}{ Pgt-code } & \multirow{5}{*}{$\begin{array}{c}\text { Subset }^{\mathbf{a}} \\
\mathbf{1} \\
2 \\
3 \\
4\end{array}$} & \multicolumn{4}{|c|}{ Infection type produced on host lines with $S r$} \\
\hline & & 5 & 21 & $9 e$ & $7 b$ \\
\hline & & 11 & 6 & $8 a$ & $9 \mathrm{~g}$ \\
\hline & & 36 & $9 b$ & 30 & 17 \\
\hline & & 9a & 9d & 10 & $\operatorname{Tmp}$ \\
\hline B & & Low & Low & Low & Low \\
\hline $\mathrm{C}$ & & Low & Low & Low & High \\
\hline D & & Low & Low & High & Low \\
\hline $\mathrm{F}$ & & Low & Low & High & High \\
\hline $\mathrm{G}$ & & Low & High & Low & Low \\
\hline $\mathrm{H}$ & & Low & High & Low & High \\
\hline $\mathrm{J}$ & & Low & High & High & Low \\
\hline $\mathrm{K}$ & & Low & High & High & High \\
\hline $\mathrm{L}$ & & High & Low & Low & Low \\
\hline M & & High & Low & Low & High \\
\hline $\mathrm{N}$ & & High & Low & High & Low \\
\hline $\mathrm{P}$ & & High & Low & High & High \\
\hline Q & & High & High & Low & Low \\
\hline $\mathrm{R}$ & & High & High & Low & High \\
\hline $\mathrm{S}$ & & High & High & High & Low \\
\hline $\mathrm{T}$ & & High & High & High & High \\
\hline
\end{tabular}

a Pgt-code consists of the designation for subset 1 followed by that for subset 2, etc. 
Table 2. Frequency of identified races of Puccinia graminis f. sp. tritici from wheat by area and source of collection in 1995

\begin{tabular}{|c|c|c|c|c|c|c|c|c|c|}
\hline \multirow[b]{2}{*}{ Area $^{a}$} & \multirow[b]{2}{*}{ Source } & \multirow{2}{*}{$\begin{array}{c}\text { Collections } \\
(\text { no. })^{b}\end{array}$} & \multirow{2}{*}{$\begin{array}{c}\text { Isolates } \\
\text { (no.) }\end{array}$} & \multicolumn{6}{|c|}{ Percentage of each Pgt physiologic race ${ }^{c}$} \\
\hline & & & & QCCJ & QCCS & QCMS & QFCS & RCMS & TPMK \\
\hline $1 \mathrm{~N}$ & Nursery & 2 & 6 & 50 & $\ldots$ & $\ldots$ & $\ldots$ & $\ldots$ & 50 \\
\hline \multirow[t]{3}{*}{$1 \mathrm{~S}$} & Field & 3 & 9 & $\ldots$ & $\ldots$ & $\ldots$ & $\ldots$ & 67 & 33 \\
\hline & Nursery & 4 & 8 & $\ldots$ & $\ldots$ & $\ldots$ & 38 & 50 & 13 \\
\hline & Total & 7 & 17 & $\ldots$ & $\ldots$ & $\ldots$ & 18 & 59 & 24 \\
\hline \multirow[t]{3}{*}{2} & Field & 3 & 9 & $\ldots$ & $\ldots$ & $\ldots$ & $\ldots$ & $\ldots$ & 100 \\
\hline & Nursery & 14 & 41 & 7 & $\ldots$ & $\ldots$ & $\ldots$ & 7 & 85 \\
\hline & Total & 17 & 50 & 6 & $\ldots$ & $\ldots$ & $\ldots$ & 6 & 88 \\
\hline \multirow[t]{2}{*}{3} & Nursery & 4 & 10 & 20 & $\ldots$ & $\ldots$ & 40 & $\ldots$ & 40 \\
\hline & Nursery & 2 & 6 & $\ldots$ & $\ldots$ & $\ldots$ & $\ldots$ & $\ldots$ & 100 \\
\hline 5 & Nursery & 6 & 18 & 50 & $\ldots$ & $\ldots$ & 33 & 6 & 11 \\
\hline 6 & Nursery & 21 & 63 & 54 & 5 & $\ldots$ & 37 & $\ldots$ & 5 \\
\hline 7 & Nursery & 1 & 3 & 67 & $\ldots$ & $\ldots$ & $\ldots$ & $\ldots$ & 33 \\
\hline \multirow[t]{3}{*}{8} & Field & 1 & 3 & $\ldots$ & $\ldots$ & $\ldots$ & $\ldots$ & $\ldots$ & 100 \\
\hline & Nursery & 8 & 22 & 5 & 23 & 18 & 14 & $\ldots$ & 41 \\
\hline & Total & 9 & 25 & 4 & 20 & 16 & 12 & $\ldots$ & 48 \\
\hline \multirow[t]{3}{*}{ U.S. } & Field & 6 & 18 & $\ldots$ & $\ldots$ & $\ldots$ & $\ldots$ & 33 & 67 \\
\hline & Nursery & 54 & 155 & 34 & 2 & $\ldots$ & 23 & 5 & 35 \\
\hline & Total & 60 & 173 & 31 & 2 & $\ldots$ & 21 & 8 & 39 \\
\hline
\end{tabular}

a See Figure 1A. Area 8 not included in U.S. totals.

b Uredinia from a single field, plant, or cultivar constituted a collection from which up to three single uredinia (isolates) were identified.

c International Pgt races (15); set four includes $\operatorname{Sr} 9 \mathrm{a}, 9 \mathrm{~d}, 10$, and $\mathrm{Tmp}$.

Table 3. Incidence of virulence in isolates of Puccinia graminis f. sp. tritici from wheat toward single gene differential wheat lines in the 1995 survey

\begin{tabular}{|c|c|c|c|c|c|c|c|c|c|c|c|c|c|c|c|c|c|c|}
\hline \multirow[b]{2}{*}{ Area $^{a}$} & \multirow[b]{2}{*}{ Source } & \multirow[b]{2}{*}{ Isolates } & \multicolumn{16}{|c|}{ Percentage of isolates virulent to $S r$ gene } \\
\hline & & & 5 & 6 & $7 b$ & $8 \mathbf{a}$ & $9 a$ & $9 b$ & 9d & $9 e$ & $9 \mathrm{~g}$ & 10 & 11 & 17 & 21 & 30 & 36 & Tmp \\
\hline \multirow[t]{3}{*}{ U.S. } & Field & 18 & 100 & 0 & 100 & 67 & 33 & 0 & 100 & 67 & 100 & 100 & 67 & 100 & 100 & 0 & 100 & 67 \\
\hline & Nursery & 155 & 100 & 0 & 41 & 59 & 30 & 0 & 100 & 35 & 100 & 100 & 35 & 100 & 100 & 0 & 41 & 35 \\
\hline & Total & 173 & 100 & 0 & 47 & 60 & 31 & 0 & 100 & 39 & 100 & 100 & 39 & 100 & 100 & 0 & 47 & 39 \\
\hline $1 \mathrm{~N}$ & Nursery & 6 & 100 & 0 & 50 & 50 & 0 & 0 & 100 & 50 & 100 & 100 & 50 & 100 & 100 & 0 & 50 & 50 \\
\hline \multirow[t]{3}{*}{$1 \mathrm{~S}$} & Field & 9 & 100 & 0 & 100 & 33 & 67 & 0 & 100 & 33 & 100 & 100 & 33 & 100 & 100 & 0 & 100 & 33 \\
\hline & Nursery & 8 & 100 & 0 & 63 & 50 & 88 & 0 & 100 & 13 & 100 & 100 & 13 & 100 & 100 & 0 & 63 & 13 \\
\hline & Total & 17 & 100 & 0 & 82 & 41 & 76 & 0 & 100 & 24 & 100 & 100 & 24 & 100 & 100 & 0 & 82 & 24 \\
\hline \multirow[t]{3}{*}{2} & Field & 9 & 100 & 0 & 100 & 100 & 0 & 0 & 100 & 100 & 100 & 100 & 100 & 100 & 100 & 0 & 100 & 100 \\
\hline & Nursery & 41 & 100 & 0 & 93 & 85 & 7 & 0 & 100 & 85 & 100 & 100 & 85 & 100 & 100 & 0 & 93 & 85 \\
\hline & Total & 50 & 100 & 0 & 94 & 88 & 6 & 0 & 100 & 88 & 100 & 100 & 88 & 100 & 100 & 0 & 94 & 88 \\
\hline 3 & Nursery & 10 & 100 & 0 & 40 & 80 & 40 & 0 & 100 & 40 & 100 & 100 & 40 & 100 & 100 & 0 & 40 & 40 \\
\hline 4 & Nursery & 6 & 100 & 0 & 100 & 100 & 0 & 0 & 100 & 100 & 100 & 100 & 100 & 100 & 100 & 0 & 100 & 100 \\
\hline 5 & Nursery & 18 & 100 & 0 & 17 & 44 & 39 & 0 & 100 & 11 & 100 & 100 & 11 & 100 & 100 & 0 & 17 & 11 \\
\hline 6 & Nursery & 63 & 100 & 0 & 5 & 41 & 41 & 0 & 100 & 5 & 100 & 100 & 5 & 100 & 100 & 0 & 5 & 5 \\
\hline 7 & Nursery & 3 & 100 & 0 & 33 & 33 & 0 & 0 & 100 & 33 & 100 & 100 & 33 & 100 & 100 & 0 & 33 & 33 \\
\hline U.S. & $1994^{\mathrm{b}}$ & & 100 & 5 & 48 & 71 & 35 & 8 & 100 & 39 & 100 & 95 & 40 & 94 & 100 & 0 & 48 & 39 \\
\hline U.S. & $1993^{c}$ & & 100 & $* \mathrm{~d}$ & 57 & 76 & 19 & $*$ & 100 & 57 & 100 & 99 & 57 & 100 & 100 & 0 & 57 & 57 \\
\hline U.S. & $1992^{\mathrm{e}}$ & & 100 & 0 & 31 & 44 & 19 & 0 & 100 & 31 & 100 & 98 & 31 & 100 & 100 & 0 & 31 & 31 \\
\hline U.S. & $1991^{\mathrm{f}}$ & & 100 & 0 & 18 & 32 & 14 & 0 & 100 & 18 & 100 & 100 & 17 & 100 & 100 & 0 & 18 & 17 \\
\hline
\end{tabular}

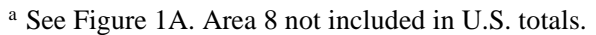

b 1994 McVey et al. (2). Does not include Hordeum collections.

c 1993 Roelfs et al. (14). Includes Hordeum collections.

$\mathrm{d} *=$ Less than $0.6 \%$.

e 1992 Roelfs et al. (13).

f 1991 Roelfs et al. (12).

Table 4. Frequency of identified races of Puccinia graminis f. sp. tritici from Hordeum vulgare and H. jubatum by race and source

\begin{tabular}{|c|c|c|c|c|c|c|c|c|}
\hline \multirow[b]{2}{*}{$\operatorname{Area}^{\mathbf{a}}$} & \multirow[b]{2}{*}{ Source } & \multirow{2}{*}{$\begin{array}{l}\text { Collections } \\
(\text { no. })^{\text {b }}\end{array}$} & \multirow{2}{*}{$\begin{array}{c}\text { Isolates } \\
\text { (no.) }\end{array}$} & \multicolumn{5}{|c|}{ Percentage of each Pgt physiologic race } \\
\hline & & & & QCCJ & QCCS & QFCS & RCMS & TPMK \\
\hline 2 & Nursery & 1 & 3 & $\ldots$ & $\ldots$ & $\ldots$ & $\ldots$ & 100 \\
\hline 5 & Nursery & 4 & 12 & 83 & $\ldots$ & $\ldots$ & 17 & $\ldots$ \\
\hline \multirow[t]{3}{*}{6} & Field & 20 & 58 & 100 & $\ldots$ & $\ldots$ & $\ldots$ & $\ldots$ \\
\hline & Nursery & 22 & 65 & 92 & 3 & 3 & 2 & $\ldots$ \\
\hline & Total & 42 & 123 & 96 & 2 & 2 & 1 & $\ldots$ \\
\hline \multirow[t]{3}{*}{ U.S. } & Field & 20 & 58 & 100 & $\ldots$ & $\ldots$ & $\ldots$ & $\ldots$ \\
\hline & Nursery & 27 & 80 & 88 & 3 & 3 & 4 & 4 \\
\hline & Total & 47 & 138 & 93 & 1 & 1 & 2 & 2 \\
\hline
\end{tabular}

a See Figure $1 \mathrm{~A}$

${ }^{\mathrm{b}}$ Uredinia from a single field, plant, or cultivar constituted a collection, from which up to three single uredinia (isolates) were identified.

c International Pgt races (15); set four includes $\operatorname{Sr} 9 \mathrm{a}, 9 \mathrm{~d}, 10$, and Tmp. 
Visual inspections for the presence of rust, using the modified Cobb scale (3), were made at commercial fields (4 to 50 ha) every $32 \mathrm{~km}$, or in the first field thereafter. Additional inspections were made at experimental nurseries and wheat trap plots along the route. Techniques used in the surveys and their interpretations have been described $(6,7,10)$. Whenever rust was observed in a field or nursery, leaves or stems bearing rust uredinia from a single cultivar or field were collected. Addi-
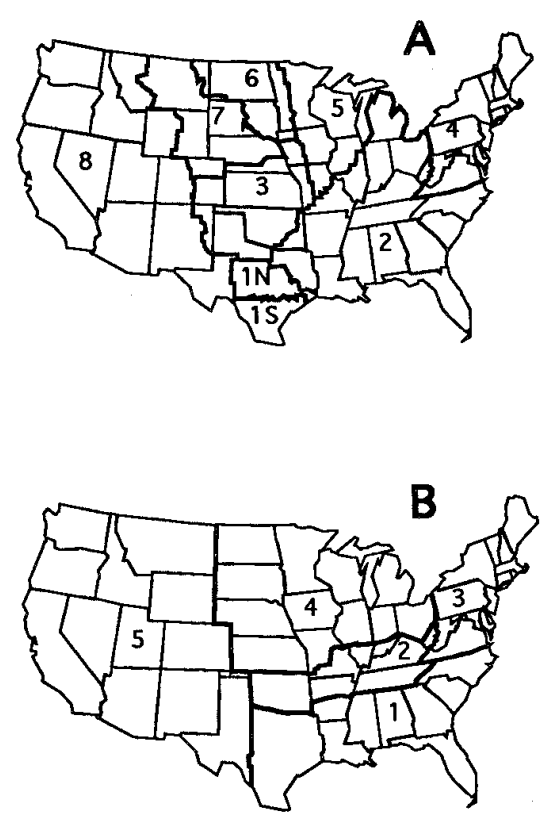

Fig. 1. Ecological areas for Puccinia graminis in the United States. (A) Areas of wheat stem rust: $1 \mathrm{~S}$, fall seeded facultative and spring wheats, overwintering foci; $1 \mathrm{~N}$, mixed winter wheat types, rare overwintering uredinia; 2, soft red winter wheat, scattered overwintering foci; 3 , southern hard red winter wheat; 4, mostly soft red winter wheat and barberry; 5 , isolated fields of mixed wheat types; 6 , hard red spring and durum wheat; 7 , northern hard red winter wheat; and 8 , mostly soft winter wheat, spring wheat, and barberry. (B) Areas of oat stem rust: 1 , winter oats, occasional overwintering uredinia; 2, mixed winter and spring oats, rare overwintering uredinia; 3 , spring oats and barberry; 4 , spring oats; and 5 , isolated oat fields, overwintering uredinia in southern California. tional collections were furnished by cooperators.

A portion of each collection was used to inoculate 7-day-old seedlings of a susceptible cultivar (when the rust forma specialis was known) or a group of potentially susceptible host species (if the forma specialis was unknown). Spores suspended in lightweight mineral oil were sprayed on plants, which were then placed in a dew chamber overnight at $18^{\circ} \mathrm{C}$. The inoculated plants had been treated with maleic hydrazide to enhance spore production (16). Following $14 \mathrm{~h}$ of darkness, VHO fluorescent light was provided for 3 to $4 \mathrm{~h}$ while the temperature gradually rose to $25^{\circ} \mathrm{C}$ to enhance fungal penetration. Plants were then placed in a greenhouse at 18 to $28^{\circ} \mathrm{C}$, where each culture was maintained in a separate clear plastic chamber. After 12 to 14 days, up to four host species plants, each bearing a uredinium or pruned to bear a uredinium, were saved and reincubated (free water, $18^{\circ} \mathrm{C}, 3$-h minimum) to permit free urediniospores to germinate. About 4 days later, urediniospores were collected from each uredinium (each considered an isolate); each uredinium provided enough spores to inoculate a differential host series.

The second collection of spores was made from each uredinium and bulked with those from other collections made in the same area and at the same time. The bulked spores were sprayed on the "universally" resistant series.

P. graminis f. sp. tritici. The differential host series consisted of wheat lines with resistance genes $\operatorname{Sr} 5,6,7 \mathrm{~b}, 8 \mathrm{a}, 9 \mathrm{~b}, 9 \mathrm{e}, 9 \mathrm{~g}$, 11, 17, 21, 30, and 36 (Table 1). Races were assigned using the International Pgtcode (15). An additional differential set, consisting of lines $S r 9 \mathrm{a}, 9 \mathrm{~d}, 10$, and Tmp, was added. The universally resistant wheat series consisted of lines with resistance genes $\operatorname{Sr} 13,22,24,25,26,27,29,31,32$, 33, 37, Gt and Wld-1 and the cultivars Era, Cando, and Ward, which were selected over a period of years as resistant to stem rust (12). Data were grouped by ecological areas (Fig. 1A) based on cultural practices, geographic separation, and wheat production.

$P$. graminis f. sp. avenae. The differential host series for identifying races of $P$. graminis f. sp. avenae consisted of oat lines with resistance genes $P g-1,-2,-3,-4$, $-8,-9,-13,-15,-16$, and $-a$. Races were assigned using the NA race nomenclature (1). The universally resistant oat series consisted of the host lines Saia (CI 7010), CI 7221, S.E.S. No. 52 (CI 3034), X-15882 (CI 8457), Kyto (CI 8250), MN 730358, and CI 9139, which were selected over a period of years as resistant to stem rust (11). Data were grouped by ecological areas (Fig. 1B) based on oat production, cultural practices, and geographic separation.

\section{RESULTS AND DISCUSSION}

$P$. graminis f. sp. tritici. Overwintering sites were found in southern Texas, Louisiana, southwestern Georgia, northeastern Arkansas, and southwestern South Carolina. During the last week of March, trace amounts of stem rust were found in winter wheat fields southwest of Houston, southeast of San Antonio, and in a nursery at Beeville, Texas. In mid-April, trace to $5 \%$ severities were found in commercial fields of the cultivars CK9835 and Savannah in central Louisiana. By late April, traces were found in winter wheat plots from central Texas to southwestern South Carolina. In early May, stem rust was severe on susceptible cultivars in southern and central Texas nurseries. By mid-May, light severities surrounded overwintering sites in the cultivar CK9835 in northeast Arkansas, and susceptible cultivars in plots in northeastern South Carolina. By the third week of May, severe stem rust was found in plots of the cultivars Saluda and Chisholm, respectively, in northeastern Arkansas and southwestern Oklahoma, and a week later in southwestern Missouri. In the second week of June, wheat stem rust was observed in fields of soft red winter wheat in southern Illinois and wheat plots in southwestern Indiana. By mid-June, traces were found in west central Indiana.

By late June, $10 \%$ stem rust severities were reported in northeastern and northwestern Kansas in trap plots of susceptible winter wheat cultivar McNair 701 at hard dough. On 19 June, traces of stem rust were found on the susceptible spring wheat cultivar Baart (trap plots) in southern Min-

Table 5. Incidence of virulence in isolates of Puccinia graminis f. sp. tritici from Hordeum vulgare and $H$. jubatum toward single gene differential wheat lines in the 1995 survey

\begin{tabular}{|c|c|c|c|c|c|c|c|c|c|c|c|c|c|c|c|c|c|c|}
\hline \multirow[b]{2}{*}{ Area $^{a}$} & \multirow[b]{2}{*}{ Source } & \multirow[b]{2}{*}{ Isolates } & \multicolumn{16}{|c|}{ Percentage of isolates virulent to $S r$ gene } \\
\hline & & & 5 & 6 & $7 b$ & $8 \mathbf{a}$ & $9 \mathbf{a}$ & $9 b$ & 9d & $9 e$ & $9 \mathrm{~g}$ & 10 & 11 & 17 & 21 & 30 & 36 & $T m p$ \\
\hline \multirow[t]{3}{*}{ U.S. } & Field & 58 & 100 & 0 & 0 & 0 & 0 & 0 & 100 & 0 & 100 & 100 & 0 & 100 & 100 & 0 & 0 & 0 \\
\hline & Nursery & 80 & 100 & 0 & 8 & 6 & 9 & 0 & 100 & 4 & 100 & 100 & 4 & 100 & 100 & 0 & 8 & 4 \\
\hline & Total & 138 & 100 & 0 & 4 & 4 & 5 & 0 & 100 & 2 & 100 & 100 & 2 & 100 & 100 & 0 & 4 & 2 \\
\hline 2 & Nursery & 3 & 100 & 0 & 100 & 100 & 0 & 0 & 100 & 100 & 100 & 100 & 100 & 100 & 100 & 0 & 100 & 100 \\
\hline 5 & Nursery & 12 & 100 & 0 & 17 & 0 & 17 & 0 & 100 & 0 & 100 & 100 & 0 & 100 & 100 & 0 & 17 & 0 \\
\hline \multirow[t]{3}{*}{6} & Field & 58 & 100 & 0 & 0 & 0 & 100 & 0 & 100 & 0 & 100 & 100 & 0 & 100 & 100 & 0 & 0 & 0 \\
\hline & Nursery & 65 & 100 & 0 & 2 & 3 & 8 & 0 & 100 & 0 & 100 & 100 & 0 & 100 & 100 & 0 & 2 & 0 \\
\hline & Total & 123 & 100 & 0 & 1 & 2 & 4 & 0 & 100 & 0 & 100 & 100 & 0 & 100 & 100 & 0 & 1 & 0 \\
\hline U.S. & 1994 & & 100 & 3 & 6 & 8 & 8 & 3 & 100 & 3 & 100 & 97 & 6 & 97 & 100 & 0 & 6 & 3 \\
\hline
\end{tabular}

${ }^{a}$ See Figure 1A. 
nesota. In early July, traces of stem rust were found in a hard red winter wheat plot in southeastern North Dakota. By mid-July, traces were found in trap plots of the susceptible cultivar Baart in east central South Dakota, southeastern North Dakota, and west central Minnesota.

The stem rust population overwintering north of Texas was smaller than normal. Cool dry weather conditions in late winter in the southern Plains and hot dry weather in late May and early June in the central Plains were not favorable for stem rust development or spread northward. The commercial spring and durum wheats are resistant to stem rust. Incidence of resistant type uredinia was low and losses were negligible.

Six races were identified from 60 wheat collections in 1995 (Table 2). Races
TPMK, QCCJ, and QFCS consisted of 39, 31 , and $21 \%$ of the isolates, respectively. Only races TPMK (67\%) and RCMS $(33 \%)$ were identified from seven (25 isolates) field (areas 1S, 2, and 8) collections. The other four races identified were QCCS, QCMS, QFCS, and RCMS. Races RCRS, RKQQ, and RTQQ, detected in 1994, were not detected in 1995. Wheat stem rust races $\mathrm{BBBB}, \mathrm{BFBJ}$, and RCMS were identified from Minnesota $B$. vulgaris collections, and RCMS was identified from an unknown grass collection. The incidences of virulence to single gene lines used for race identification are shown in Table 3. No virulence was found to wheat lines with $\operatorname{Sr} 6,9 b, 13,22,24,25,26,27$, 29, 30, 31, 32, 37, Gt, and Wld-1.

Forty-one stem rust collections from Hordeum vulgare $\mathrm{L}$. and six from $H$.

Table 6. Frequency of identified races of Puccinia graminis f. sp. avenae by area and source of collection in 1995

\begin{tabular}{|c|c|c|c|c|c|c|}
\hline \multirow[b]{2}{*}{ Area $^{\mathbf{a}}$} & \multirow[b]{2}{*}{ Source } & \multirow{2}{*}{$\begin{array}{l}\text { Collections } \\
(\text { (no. })^{\mathrm{b}}\end{array}$} & \multirow{2}{*}{$\begin{array}{c}\text { Isolates } \\
\text { (no.) }\end{array}$} & \multicolumn{3}{|c|}{$\begin{array}{l}\text { Percentage of each North American } \\
\text { (NA) physiologic race }\end{array}$} \\
\hline & & & & NA-5 & NA-16 & NA-27 \\
\hline \multirow[t]{3}{*}{1} & Field & 3 & 9 & $\ldots$ & 22 & 78 \\
\hline & Nursery & 59 & 164 & $\ldots$ & 16 & 84 \\
\hline & Total & 62 & 173 & $\ldots$ & 16 & 84 \\
\hline 2 & Nursery & 1 & 3 & $\ldots$ & $\ldots$ & 100 \\
\hline 3 & Field & 1 & 3 & $\ldots$ & $\ldots$ & 100 \\
\hline \multirow[t]{3}{*}{4} & Field & 4 & 12 & $\ldots$ & 25 & 75 \\
\hline & Nursery & 9 & 25 & $\ldots$ & 4 & 96 \\
\hline & Total & 13 & 37 & $\ldots$ & 11 & 89 \\
\hline \multirow[t]{3}{*}{5} & Field & 1 & 3 & 100 & $\ldots$ & $\ldots$ \\
\hline & Nursery & 2 & 6 & 100 & $\ldots$ & $\ldots$ \\
\hline & Total & 3 & 9 & 100 & $\ldots$ & $\ldots$ \\
\hline \multirow[t]{3}{*}{ U.S. } & Field & 9 & 27 & 11 & 19 & 70 \\
\hline & Nursery & 71 & 198 & 3 & 14 & 83 \\
\hline & Total & 80 & 225 & 4 & 14 & 82 \\
\hline
\end{tabular}

${ }^{a}$ See Figure 1B.

${ }^{\mathrm{b}}$ Uredinia from a single field, plant, or cultivar received separately constituted a collection from which up to three single uredinia (isolates) were identified.

${ }^{\mathrm{c}}$ Martens et al. (1).

jubatum yielded 138 isolates of $P$. graminis f. sp. tritici (Table 4). Race QCCJ constituted $93 \%$ of the isolates from fields and nurseries, while the other races (TPMK, QCCS, QFBS, and RCMS) constituted 2\% or less of the isolates. The incidences of virulence of $P$. graminis $\mathrm{f}$. sp. tritici from $H$. vulgare and $H$. jubatum are shown in Table 5. Six collections from $H$. jubatum from region 6 yielded six isolates each of races QCCJ and QFCS, and one of TPMK. Race QCCJ is virulent on Rpg-1 (T-gene), which all $H$. vulgare cultivars presently grown are assumed to possess. Rpg- 1 is absent in $H$. jubatum.

P. graminis f. sp. avenae. Overwintering sites were observed (trace to 20\%) in experimental plots at Beeville and Temple, Texas, and in a field $80 \mathrm{~km}$ southwest of San Antonio. In late February, oat stem rust was also observed in experimental plots in southern Louisiana. In general, there was less oat stem rust and it was slower to develop in this area than last year because of cool weather in early February and March. In the last week of April, trace to $20 \%$ severities were reported in plots in central and north central Texas, and stem rust was severe in the plots by the first week of May. The relative lack of oat production in the Great Plains interrupted the potential for an epidemic farther north. During the last week of June, 2\% severity was found on oats in northeastern Indiana.

The first detection of oat stem rust in the north central Plains was in the first week in July, when traces were found on wild oats (A. fatua) growing alongside a road in southeastern North Dakota. In mid-July, traces of oat stem rust were in plots in east central Minnesota, but none was found during the disease survey through eastern South and North Dakota.

Table 7. Incidence of virulence in isolates of Puccinia graminis f. sp. avenae toward single gene differential oat lines in the 1995 survey

\begin{tabular}{|c|c|c|c|c|c|c|c|c|}
\hline \multirow[b]{2}{*}{ Area $^{\mathbf{a}}$} & \multirow[b]{2}{*}{ Source } & \multirow[b]{2}{*}{ Isolates } & \multicolumn{6}{|c|}{ Percentage of isolates virulent to $P g$ gene $^{\mathrm{b}}$} \\
\hline & & & 1 & 2 & 3 & 4 & 8 & 15 \\
\hline 1 & Field & 9 & 100 & 78 & 100 & 78 & 100 & 0 \\
\hline 2 & Nursery & 3 & 100 & 100 & 100 & 100 & 100 & 0 \\
\hline 3 & Field & 3 & 100 & 100 & 100 & 100 & 100 & 0 \\
\hline \multirow[t]{3}{*}{4} & Field & 12 & 100 & 75 & 100 & 75 & 100 & 0 \\
\hline & Nursery & 25 & 100 & 96 & 100 & 96 & 100 & 0 \\
\hline & Total & 37 & 100 & 89 & 100 & 89 & 100 & 0 \\
\hline \multirow[t]{3}{*}{5} & Field & 3 & 0 & 0 & 100 & 0 & 0 & 100 \\
\hline & Nursery & 6 & 0 & 0 & 100 & 0 & 0 & 100 \\
\hline & Total & 9 & 0 & 0 & 100 & 0 & 0 & 100 \\
\hline \multirow[t]{3}{*}{ U.S. } & Field & 27 & 89 & 70 & 100 & 70 & 89 & 11 \\
\hline & Nursery & 34 & 82 & 79 & 100 & 79 & 82 & 18 \\
\hline & Total & 61 & 85 & 75 & 100 & 75 & 85 & 15 \\
\hline U.S. & $1994^{c}$ & $\ldots$ & 98 & 97 & 100 & 97 & 98 & 2 \\
\hline U.S. & $1993^{\mathrm{d}}$ & $\begin{array}{l}\cdots \\
\cdots\end{array}$ & 81 & 91 & 81 & 81 & 81 & 19 \\
\hline U.S. & $1992^{\mathrm{e}}$ & $\ldots$ & 98 & 91 & 100 & 90 & 98 & 2 \\
\hline U.S. & $1991^{\mathrm{f}}$ & $\ldots$ & 97 & 93 & 100 & 93 & 97 & 3 \\
\hline
\end{tabular}

${ }^{a}$ See Figure 1B.

b No virulence found on $P g-9,-13,-16,-a$, from 1990 to 1995.

c McVey et al. (2).

${ }^{\mathrm{d}}$ Roelfs et al. (14)

${ }^{\mathrm{e}}$ Roelfs et al. (13).

${ }^{\mathrm{f}}$ Roelfs et al. (12). 
Race NA-27, virulent to $P g-1,-2,-3,-4$, and -8 , was predominant, consisting of $82 \%$ of 225 isolates from 80 collections in 1995 (Table 6). Races NA5, virulent to $P g$ 3 and -15 , and NA16, virulent to $P g-1,-3$, and -8 , constituted 4 and $14 \%$ of the isolates, respectively, from the United States. Only race NA29, virulent to $P g-1,-2,-3$, $-4,-8$, and -15 , was identified from four collections from Mexico. Terminal severities were light and little loss occurred.

The incidence of virulence to single gene lines used for the race identification is shown in Table 7. Hosts having genes $P g-9$, $-13,-16$, and $-a$ were resistant to the population samples from the United States. No virulence was detected to the oat lines in the resistant series.

\section{ACKNOWLEDGMENTS}

We thank Mark Hughes for assistance with data processing and tabulation, and David H. Casper for assistance with the survey.

\section{LITERATURE CITED}

1. Martens, J. W., Roelfs, A. P., McKenzie, R. I. H., Rothman, P. G., Stuthman, D. D., and
Brown, P. D. 1979. System of nomenclature for races of Puccinia graminis f. sp. avenae. Phytopathology 69:293-294.

2. McVey, D. V., Long, D. L., and Roberts, J. J. 1996. Races of Puccinia graminis in the United States during 1994. Plant Dis. 80:8589.

3. Peterson, R. F., Campbell, A. B., and Hannah, A. E. 1948. A diagrammatic scale for estimating rust intensity on leaves and stems of cereals. Can. J. Res. C. 26:496-500.

4. Roelfs, A. P. 1978. Estimated losses caused by rust in small grain cereals in the United States - 1918-1976. U.S. Dep. Agric., Agric. Res. Serv., Misc. Publ. No. 1363.

5. Roelfs, A. P. 1982. Effects of barberry eradication on stem rust in the United States. Plant Dis. 66:177-181.

6. Roelfs, A. P. 1985. Epidemiology in North America. Pages 403-434 in: The Cereal Rusts. Vol. II, Diseases, Distribution, Epidemiology, and Control. A. P. Roelfs and W. R. Bushnell, eds. Academic Press, Orlando, FL.

7. Roelfs, A. P. 1990. Epidemiology of the cereal rusts in North America. Can. J. Plant Pathol. 11:86-90.

8. Roelfs, A. P., and Groth, J. V. 1980. A comparison of virulence phenotypes in wheat stem rust populations reproducing sexually and asexually. Phytopathology 70:855-862.

9. Roelfs, A. P., and Long, D. L. 1980. Analysis of recent oat stem rust epidemics. Phytopathology 70:436-440.

10. Roelfs, A. P., and Long, D. L. 1987. Puccinia graminis development in North America during 1986. Plant Dis. 71:1089-1093.

11. Roelfs, A. P., Long, D. L., and Roberts, J. J. 1993. Races of Puccinia graminis in the United States during 1990. Plant Dis. 77:125128.

12. Roelfs, A. P., Long, D. L., and Roberts, J. J. 1993. Races of Puccinia graminis in the United States during 1991. Plant Dis. 77:129. 132.

13. Roelfs, A. P., Long, D. L., and Roberts, J. J. 1993. Races of Puccinia graminis in the United States during 1992. Plant Dis.77:11221125

14. Roelfs, A. P., Long, D. L., and Roberts, J. J. 1995. Races of Puccinia graminis in the United States during 1993. Plant Dis. 79:969972.

15. Roelfs, A. P., and Martens, J. W. 1988. An international system of nomenclature for Puccinia graminis f. sp. tritici. Phytopathology 78:526-533.

16. Rowell, J. B. 1984. Controlled infection by Puccinia graminis f. sp. tritici. Pages 291-332 in: The Cereal Rusts. Vol. I, Origins, Specificity, Structure, and Physiology. W. R. Bushnell and A. P. Roelfs, eds. Academic Press, Orlando, FL. 